https://nv.nltu.edu.ua

https://doi.org/10.15421/40281009

Article received 22.10.2018 p.

Article accepted 29.11.2018 p.

$@ \bowtie$ Correspondence author

удк 630*228(477.41)

Л. П. Степаненко

ВП НУБіП України "Боярський коледж екології і природних ресурсів", м. Боярка, Украӥна

\title{
ДИНАМІКА ЗАПАСІВ І ПЛОЩ ГОЛОВНИХ ЛІСОТВІРНИХ ПОРІД КИЇВСЬКОЇ ОБЛАСТІ
}

Важливим показником оцінки лісостану є його продуктивність, тому важливою проблемою лісового господарства $є$ питання 3 підвищення продуктивності лісів. Проведено аналіз та виявлено закономірності збільшення основних показників продуктивності насаджень Київської області за шість періодів обліку лісового фонду від 1978 р. до 2011 р. та наведено їхню характеристику. Встановлено збільшення лісистості на 2,4 \%, водночас відбулося зменшення площі вкритих лісовою рослинністю лісових ділянок загалом в області, що пов'язано з територіальними та адміністративними змінами. Також встановлено збільшення запасів як загалом, так і на один гектар. Це відображає ефективність лісогосподарьких заходів. Виявлено зменшення відсотка запасів м'яколистяних завдяки збільшенню хвойних та твердолистяних деревостанів. У регіоні досліджень найпоширеніші такі деревні види: 3 групи хвойних порід - сосна звичайна, з групи твердолистяних - дуб звичайний, 3 групи м'яколистяних - береза повисла, вільха клейка, осика. Одним із показників продуктивності деревостанів $є$ бонітет. Встановлено, що середні класи бонітету насаджень є досить високі, що свідчить про те, що підбір головних лісотвірних порід у Київській області відповідає їх географічному середовищу та умовам місцезростання. 3'ясовано, що насадження Київщини не оптимальні. Це видно з вікової структури деревостанів.

Ключові слова: деревостан; бонітет; середній запас; лісистість; лісорослинні зони; вікова структура.

Вступ. Ліси нині вкривають третину земної поверхні, тому їх вважають найважливішим компонентом біосфери. Їхня у житті людства багатогранна: ліси не тільки задовольняють потреби людини в деревині, іншій лісовій продукції, а й забезпечують належний гідрологічний режим річок, захищають грунти від ерозії тощо. Останнім часом значно зросло соціальне значення лісу, що зумовлено його здатністю покращувати довкілля та сприятливо впливати на організм людини.

Ліси $є$ об'єктом ведення лісового господарства. Враховуючи довготривалість їхнього росту та формування, ведення господарства в них, справа досить складна i потребує глибоких знань біології лісу.

Важливим показником оцінки лісостану є його продуктивність. Головною проблемою лісового господарства $€$ питання $з$ підвищення продуктивності лісів і тому розуміння суті процесів, які забезпечують прискорене накопичення органічної маси, дає змогу успішно вирішувати це питання.

Вивченню біологічної продуктивності насаджень приділяли увагу багато вчених - Т. Х. Токмурзін, С. Б. Байзаков (Tokmurzin \& Baizakov, 1975), В. В. Успенський (Uspenskii, 1982), А. А. Молчанов (Molchanov, 1949) та багато інших. Вивченням цього питання в Україні багато займався Лакида П. I. (Lakida, 1986, 1996; Lakyda \& Petrenko, 2001), M. М. Петренко (Lakyda \& Petrenko, 2001) та інші. Ці вчені провели фундаментальні дослідження, які збагачують науку новою інформацією і оригінальними методологічними підходами.

Матеріали та методика дослідження. Лісові наса- дження Київської області, як об'єкт дослідження, вибрано невипадково. Вони мають специфічні особливості, які не притаманні для інших регіонів України. Територія Київщини знаходиться у двох природних зонах Поліссі й Лісостепу. Вони представлені лісостанами, які істотно відрізняються між собою.

Матеріали та методика дослідження продуктивності лісостанів Київщини, залежно від функцій, які вони виконують, території розміщення, динаміки таксаційних характеристик, які залежать не тільки від кліматичних умов, а й від господарських заходів лісокористувачів, має велике значення і $є$ предметом досліджень.

Методи дослідження, які використовували для моделювання фітомаси лісів та депонованого в ній вуглецю, складалися з характеристики окремих параметрів лісового фонду за період 1978-2011 років.

Здатність лісових екосистем акумулювати та тривало утримувати вуглець виходить на перший план. Кількість вуглецю, яку може акумулювати та утримувати лісова екосистема, передусім залежить від продуктивності насаджень.

Результати дослідження. Проведено аналіз продуктивності насаджень Київської області за період від 1978-го до 2011 років у межах лісорослинних зон та державних підприємств лісового господарства, який можна простежити за даними табл. 1.

Проаналізувавши дані, наведені в табл. 1, за досліджуваний період, відбувалося збільшення лісистості в регіоні на 2,4\%. Лісистість території області становить $20,4 \%$. Водночас, за адміністративними районами їі pi-

Інформація про автора:

Степаненко Людмила Петрівна, здобувач. Email: I.stepanenko15@ukr.net

Цитування за ДСту: Степаненко Л. П. Динаміка запасів і площ головних лісотвірних порід Київської області. Науковий вісник НЛТУ України. 2018, т. 28, № 10. С. 45-48.

Citation APA: Stepanenko, L. P. (2018). Dynamics of reserves and areas of main forest formations of Kiev region. Scientific Bulletin of UNFU, 28(10), 45-48. https://doi.org/10.15421/40281009 
вень нерівномірний і знижується 3 півночі на південь області. Якщо в зоні Київського Полісся лісистість становить $44 \%$, то в південно-східних районах (Згурівський, Яготинський р-ни), які належать до зони Лісостепу, - всього 1,9-2,0 \%.

3 даних табл. 1 видно, що загальна площа вкритих лісовою рослинністю лісових ділянок загалом в області за досліджуваний період зменшилась завдяки територіальним і адміністративним змінам.

Одним із показників продуктивності насаджень $є$ запас на одному гектарі, який зокрема відображає ефективність проведення лісогосподарських заходів.

Розподіл середніх запасів деревини на один гектар за групами лісотвірних порід та лісорослинними зонами наведено в табл. 2.

Табл. 1. Лісовий фонд ДАЛР України Київської обл. за лісорослинними зонами

\begin{tabular}{|c|c|c|c|c|c|c|c|}
\hline \multirow{2}{*}{ Лісорослинна зона } & \multirow{2}{*}{ Показники } & \multicolumn{5}{|c|}{ Рік обліку } \\
\cline { 3 - 8 } & & 1978 & 1983 & 1988 & 1996 & 2002 & 2011 \\
\hline \multirow{2}{*}{ Полісся } & площа, тис. га & 278,3 & 281,3 & 269,7 & 234,5 & 212,1 & 210,6 \\
& запас, тис. м & 38444,6 & 51956,6 & 48387,4 & 53655,7 & 53580,8 & 56938,3 \\
\hline \multirow{2}{*}{ Лісостеп } & площа, тис. га & 136,1 & 141,0 & 151,7 & 131,8 & 128,1 & 144,5 \\
& запас, тис. м & 12857,1 & 23637,3 & 28940,3 & 29823,4 & 30942,7 & 36652,4 \\
\hline \multirow{2}{*}{ Київська область } & лісистість, \% & 19,8 & 20,1 & 19,4 & 20,4 & 21,1 & 22,2 \\
& площа, тис. га & 414,4 & 410,7 & 421,4 & 366,3 & 340,2 & 355,1 \\
& запас, тис. м & 58301,7 & 75593,9 & 77327,7 & 83479,1 & 84523,5 & 93590,7 \\
\hline
\end{tabular}

Табл. 2. Розподіл середніх запасів деревини на 1 га за групами лісотвірних порід та лісорослинними зонами

\begin{tabular}{|c|c|c|c|c|c|c|c|}
\hline \multirow{2}{*}{ Лісорослинна зона } & \multirow{2}{*}{ Запас деревини, $\mathrm{m}^{3} \cdot \mathrm{ra}^{-1}$} & \multicolumn{6}{|c|}{ Рік обліку } \\
\hline & & 1978 & 1983 & 1988 & 1996 & 2002 & 2011 \\
\hline \multirow{3}{*}{ Полісся } & хвойні & 149,0 & 204,0 & 201,0 & 249,0 & 274,0 & 294,0 \\
\hline & твердолистяні & 133,0 & 149,0 & 146,0 & 189,0 & 203,0 & 219,0 \\
\hline & м'яколистяні & 101,0 & 122,0 & 121,0 & 148,0 & 164,0 & 176,0 \\
\hline \multicolumn{2}{|c|}{ Разом Полісся } & 141,0 & 188,0 & 186,0 & 229,0 & 253,0 & 271,0 \\
\hline \multirow{3}{*}{ Лісостеп } & хвойні & 164,0 & 228,0 & 221,0 & 272,0 & 298,0 & 310,0 \\
\hline & твердолистяні & 126,0 & 153,0 & 149,0 & 199,0 & 213,0 & 222,0 \\
\hline & м'яколистяні & 102,0 & 139,0 & 134,0 & 176,0 & 188,0 & 192,0 \\
\hline \multicolumn{2}{|c|}{ Разом Лісостеп } & 140,0 & 183,0 & 178,0 & 226,0 & 242,0 & 254,0 \\
\hline \multirow{3}{*}{ Київська область } & хвойні & 152,0 & 208,0 & 205,0 & 253,0 & 280,0 & 299,0 \\
\hline & твердолистяні & 128,0 & 152,0 & 148,0 & 197,0 & 211,0 & 222,0 \\
\hline & м'яколистяні & 101,0 & 125,0 & 123,0 & 154,0 & 170,0 & 182,0 \\
\hline \multicolumn{2}{|c|}{ Разом Київська область } & 141,0 & 186,0 & 184,0 & 228,0 & 248,0 & 264,0 \\
\hline
\end{tabular}

3 даних, наведених у табл. 2 можна зробити висновок, що середній запас у лісах Київської області за досліджуваний період зростає. Найвищий середній запас мають хвойні насадження 299,0 м³ , найменший - м'яколистяні $\left(101,0 \mathrm{~m}^{3}\right)$. Середні запаси в держлісгоспах у всіх групах лісотвірних порід збільшились. Наведені дані підтверджують те, що продуктивність деревостанів Київщини збільшується.

Важливим показником лісового фонду є породний склад лісів. На Київщині росте багато видів листяних і хвойних порід, таких як: сосна звичайна, дуб звичайний, береза повисла, вільха клейка, осика, які тією чи іншою мірою переважають у насадженнях. Розподіл вкритих лісовою рослинністю лісових ділянок за групами лісотвірних порід зображено на рис. 1 .

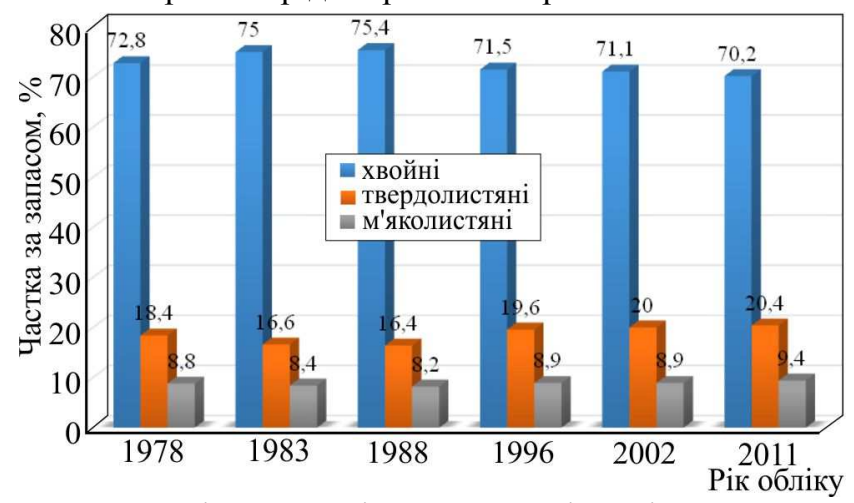

Рис. 1. Розподіл вкритих лісовою рослинністю ділянок у Київській обл. за групами лісотвірних порід

Аналіз графіка показує, що в державних підприємствах лісового господарства Київської обл. пере- важає група хвойних порід, у якій велику частку становить сосна, трапляється ялина, і чим далі з Полісся у Лісостеп частка іiї значно збільшується. У твердолистяному господарстві на території області домінує дуб. У м'яколистяному господарстві розподіл осики в межах області практично рівномірний, тоді як на Поліссі переважає береза, а в Лісостепу - вільха.

Отже, на Поліссі склались оптимальні умови для зростання сосни, дуба, берези, а в поймах річок - вільхи, частково осики та ялини. У зоні Лісостепу краще росте дуб і сосна, збільшується частка ялини та вільхи і зменшується берези.

Загалом у лісах Київської області хвойні насадження становлять 70,2 \% від площ лісів (220,0 тис. га), твердолистяні - 20,4 \% (86,1 тис. га), а м'яколистяні 9,4\% (48,4 тис. га), що відповідає існуючим лісорослинним умовам.

Також одним із найважливіших показників лісового фонду під час оцінювання лісових ресурсів $є$ структура насаджень за віком. Вона дає уявлення про площу лісів у межах груп віку і про запаси деревини, які можна використати як у поточному, так і в майбутніх десятиріччях. У віковій структурі лісів Київської обл. тепер переважають середньовікові насадження.

Зміну вікової структури насаджень у межах груп віку на початок та кінець досліджуваного періоду можна спостерігати на рис. 2. Проаналізувавши дані цього рисунка, можна зробити висновок про те, що в всіх групах порід скоротилась частка молодняків та зріс запас стиглих і перестиглих насаджень. Стабільно високою залишається частка середньовікових насаджень у межах груп порід. 
Вирішальною умовою розширеного відтворення лісових ресурсів $є$ підвищення продуктивності лісів. Продуктивність лісу залежить від багатьох чинників, типу лісорослинних умов, складу деревних порід, вікової структури і повноти насаджень. Також вплив на продуктивність лісу мають агротехнічні прийоми вирощування лісу, а також кліматичі, географічні, економічні та інші умови.

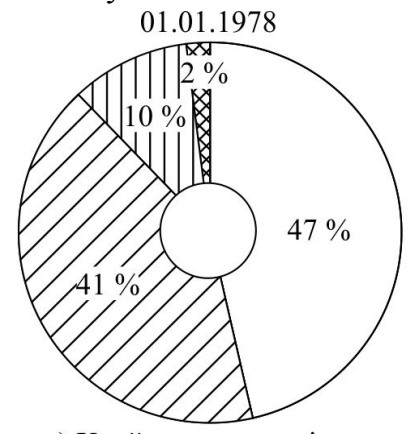

a) Хвойна група порід

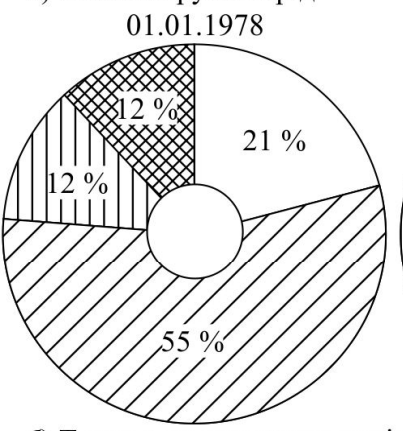

б) Твердолистяна група порід

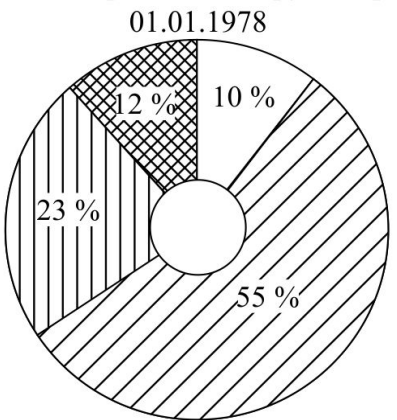

мл $\triangle$ св Ш пр ст

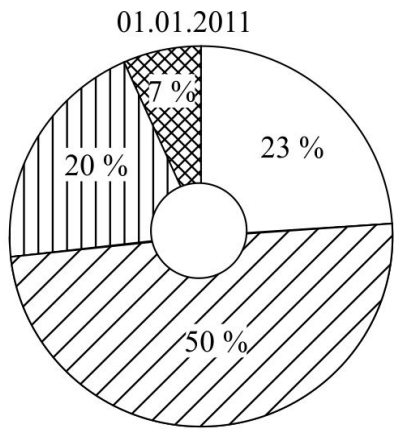

01.01 .1978
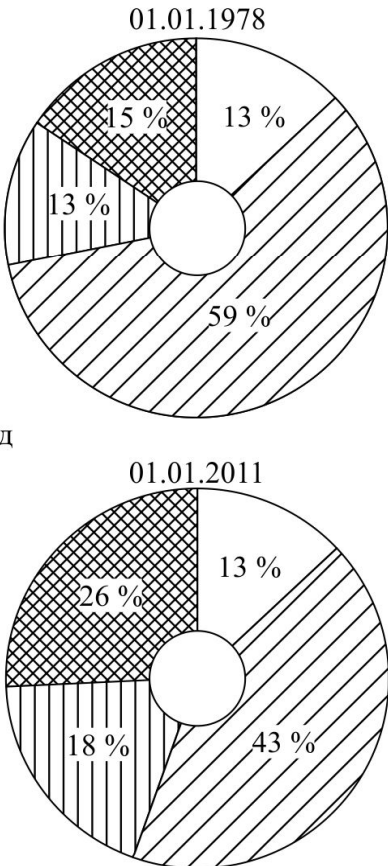

$\square$ мл $\square$ св Шпр ст в) М'яколистяна група порід

Рис. 2. Розподіл запасів деревостанів за групами віку в межах групи порід за роками обліку, \% (мл - молодняки, св - середньовікові, пр - пристиглі, ст - стиглі та перестиглі)

Табл. 3. Середні бонітети насаджень за М. М. Орловим, у межах групи порід

\begin{tabular}{|c|c|c|c|c|c|c|c|}
\hline \multirow{2}{*}{$\begin{array}{c}\text { Лicopoc- } \\
\text { линна } \\
\text { зона } \\
\end{array}$} & \multirow{2}{*}{$\begin{array}{c}\text { Частка за } \\
\text { запа- } \\
\text { сом, \% }\end{array}$} & \multicolumn{6}{|c|}{ Рік обліку } \\
\hline & & 1978 & 1983 & 1988 & 1996 & 2002 & 2011 \\
\hline \multirow{3}{*}{ Полісся } & хвойні, & $\mathrm{I}, 1$ & $\mathrm{I}, 1$ & $\mathrm{I}, 2$ & $\mathrm{I}, 1$ & $\mathrm{I}, 1$ & $\mathrm{I}, 1$ \\
\hline & листяні, & $\mathrm{I}, 4$ & $\mathrm{I}, 4$ & I,5 & $\mathrm{I}, 4$ & $\mathrm{I}, 4$ & I,9 \\
\hline & $\begin{array}{c}\text { М Яколис- } \\
\text { тяні }\end{array}$ & $\mathrm{I}, 4$ & $\mathrm{I}, 4$ & $\mathrm{I}, 4$ & $\mathrm{I}, 4$ & $\mathrm{I}, 4$ & I,7 \\
\hline \multirow{3}{*}{ Лісостеп } & хвойні, & $\mathrm{I}, 1$ & $\mathrm{I}, 1$ & $\mathrm{I}, 1$ & $\mathrm{I}, 1$ & $\mathrm{I}, 1$ & $\mathrm{I}, 1$ \\
\hline & листяні, & $\mathrm{I}, 3$ & $\mathrm{I}, 4$ & I,3 & $\mathrm{I}, 2$ & $\mathrm{I}, 1$ & I,5 \\
\hline & $\begin{array}{c}\text { мяколис- } \\
\text { тяні }\end{array}$ & $\mathrm{I}, 3$ & & $\mathrm{I}, 3$ & $\mathrm{I}, 3$ & $\mathrm{I}, 2$ & $\mathrm{I}, 3$ \\
\hline \multirow{3}{*}{$\begin{array}{c}\text { Київська } \\
\text { область }\end{array}$} & хвойні, & $\mathrm{I}, 1$ & $\mathrm{I}, 1$ & $\mathrm{I}, 2$ & $\mathrm{I}, 1$ & $\mathrm{I}, 1$ & $\mathrm{I}, 1$ \\
\hline & $\begin{array}{l}\text { твердо- } \\
\text { листяні, }\end{array}$ & $\mathrm{I}, 3$ & $\mathrm{I}, 4$ & $\mathrm{I}, 3$ & $\mathrm{I}, 2$ & $\mathrm{I}, 2$ & $\mathrm{I}, 6$ \\
\hline & $\begin{array}{c}\text { Мяколис- } \\
\text { тяні }\end{array}$ & $\mathrm{I}, 4$ & $\mathrm{I}, 4$ & $\mathrm{I}, 4$ & $\mathrm{I}, 4$ & I,3 & I,6 \\
\hline
\end{tabular}

Одним із показників продуктивності деревостанів є бонітет. Серед багатьох показників, що впливають на цей показник, є умови зростання деревостанів, правильний підбір порід відповідно до цих умов та комплекс лісогосподарських заходів, що спрямовані на підвищення продуктивності лісостанів. Середні бонітети насаджень, за М. М. Орловим, у межах групи порід наведено в табл. 3.

У лісах Київської обл. в межах груп порід переважають лісостани високої (І клас бонітетів і вище) продуктивності, а ті незначні відхилення, що відбуваються у певний час у ту чи іншу сторону, істотних змін не дають. Тобто це підтверджує попередні висновки, що підбір головних лісотвірних порід у Київській обл. відповідає їхньому географічному положенню та умовам місцезростання. На сьогодні хвойні насадження області зростають за I,1 класом бонітету, твердолистяні - I,6, а м'яколистяні - I,6.

Показники продуктивності лісів Київської обл. досить високі, але оптимального рівня вони ще не досягли.

Висновки. За досліджуваний період від 1978 р. до 2011 р. площа лісового фонду зменшилась і це пов'язано $з$ територіальними й адміністративними змінами. Середній запас на один гектар зріс майже в половину від $141,0 \mathrm{~m}^{3}$ до $264,0 \mathrm{~m}^{3}$. Лісистість у регіоні досліджень збільшилась на 2,4 \%.

Головними лісотвірними породами в Київській обл. $\epsilon$ сосна звичайна з групи хвойних порід; дуб звичайний 3 групи твердолистяних порід; береза звичайна, вільха клейка, осика 3 групи м'яколистяних порід. Вікова структура лісостанів Київщини 3 часом змінилась. Зменшилась частка за запасом молодняків та збільшився запас стиглих насаджень. Частка середньовікових насаджень є стабільно високою. У межах груп порід переважають лісостани високої продуктивності, а ті незначні відхилення, що відбуваються у певний час, істотних змін не дають. Отже, показники продуктивності Київської обл. є досить високими.

\section{Перелік використаних джерел}

Lakida, P. I. (1986). Models of growth and productivity of artificial stands of the Polesie pine tree of the Ukrainian SSR. Doctoral Dissertation for Agricultural Sciences (06.03.02 - Forest Management and Forest Taxation). Kyiv, 202 p. [In Russian].

Lakyda, P. I. (1996). Productivity of forest plantations of Ukraine by components of above-ground phytomass. Doctoral Dissertation for Agricultural Sciences (06.03.02 - Forest Management and Forest Taxation). Kyiv, 304 p. [In Ukrainian].

Lakyda, P. Y., \& Petrenko, M. M. (2001). Modeling of the dynamics of taxiological indices of forest stands of Polissya pine forest of Ukraine. Scientific Bulletin of the National Agrarian University, 34, 260-263. [In Ukrainian].

Molchanov, A. A. (1949). Conifer stocks in pine stands of various ages. Reports of the USSR Academy of Sciences, 68(5), 909-912. [In Russian].

Tokmurzin, T. Kh., \& Baizakov, S. B. (1975). Method for taxation of pine crown biomass. Forestry, 4, 41-43. [In Russian].

Uspenskii, V. V. (1982). The method of accounting for the resources of the branches in the pine forests. Forest Journal, 2, 17-20. [In Russian]. 


\title{
ДИНАМИКА ЗАПАСОВ И ПЛОЩАДЕЙ ГЛАВНЫХ ЛЕСООБРАЗУЮЩИХ ПОРОД КИЕВСКОЙ ОБЛАСТИ
}

\begin{abstract}
Исследованы закономерности увеличения основных показателей производительности насаждений Киевской области за шесть периодов учета лесного фонда и приведена их характеристика. Анализ проводился за период 1978 г. - 2011 г. Установлено увеличение лесистости на 2,4 \% в то же время произошло уменьшение площади покрытых лесной растительностью лесных участков в целом и в области. Это связано с территориальными и административными изменениями. Также установлено увеличение запасов, как в целом так и на гектар. Это отражает эффективность лесохозяйственных мероприятий, в том или ином хозяйстве. Выявлено уменьшение процента запасов мягколиственных за счет увеличения хвойных и твердолиственных древостоев. Установлено, что важным показателем лесного фонда является породный состав лесов. Наиболее распространены такие древесные породы, из группы хвойных пород - сосна обыкновенная, дуб обыкновенный из группы твердолиственных, береза повислая, ольха клейкая, осина - с мягколиственных древесных пород. Одним из показателей производительности древостоев является бонитет. Установлено, что средние бонитеты насаждений достаточно высокие, это указывает на то, что подбор главных лесообразующих пород в Киевской области соответствует их географической среде и условиям произрастания. В то же время установлено, что насаждения далеко не оптимальны. На это указывает возрастная структура древостоев, резкие отклонения других показателей производительности.
\end{abstract}

Ключевые слова: древостой; бонитет; лесообразующие породы; лесистость; лесорастительные зоны; возрастная структура.

L. P. Stepanenko

Separated subdivision of NULES of Ukraine "Boyarka College of Ecology and Natural Resources", Boyarka, Ukraine

\section{DYNAMICS OF RESERVES AND AREAS OF MAIN FOREST FORMATIONS OF KIEV REGION}

Forests are the subject of forest management. Dealing with economy is a rather complicated matter and requires a profound knowledge of the forest biology. An important indicator of the forest stand evaluation is planting productivity. Therefore, an important problem of forestry is the issue of increasing forest productivity. The forests of Kyiv Region have specific features that are not appropriate to other regions of Ukraine. The territory is located within two natural zones - Polissya and Forest-Steppe. Consequently, there are forests there that are very different in composition, main species and other tax indicators. The experimental data used to model forest phytomass and the carbon contained in it consisted of the characteristics of individual parameters of the forest fund for the period of 1978-2011. The analysis of productivity index of forest stands of Kyiv Region in the context of forest areas and state enterprises of forestry is given. Having analysed the problem, we have revealed that there was an increase in forest cover percent in the region by $2.4 \%$. Forest cover percentage of the territory is not uniform. The average stock per 1 ha has increased. The above data confirms that the productivity index of forest stands is increasing. An important indicator of the forest fund is the rock composition of the forests. Many species of deciduous and coniferous species grow in Kyiv Region, which in varying degrees predominate there. The most widespread are such coniferous tree species as Silver pine. Deciduous tree species are represented by ordinary oak, Silver birch, European alder, and aspen. One of the most important indicators of the forest fund in assessing forest resources is the structure of tree stand by age. It gives an idea of the size of the forest within the age group and on the stock of wood that can be used in both current and future decades. Many medieval plantations are still present in Kyiv Region. Productivity index of forest stands is also an important indicator. At present, coniferous plantations of the area grow in I.5 class of productivity index of forest stands, deciduous - I.6, and leafy - I.5. Performance indicators for the forests of Kyiv Region are quite high, but they have not reached the optimal level yet. Significant areas of highly productive plantings are found in the forests of Kyiv Region in different types of forest vegetation.

Keywords: tree stand; productivity index of forest stands; forestry species; forest cover; forest areas; age structure. 